\title{
Readiness to adopt e-learning: pioneering a course in school librarianship education
}

\author{
Sandy Zinn' \\ Department of Library and Information Science, University of the Western Cape \\ szinn@uwc.ac.za
}

Received 2 February 2009
Accepted 10 September 2009

\begin{abstract}
E-learning has come of age in South African higher education but scepticism, caution and an inadequate reward system for innovative teaching methods have resulted in a slow uptake by academics. Within this milieu the author pioneered a course in the ACE School Librarianship programme. The study describes the e-learning experiences of the course participants gleaned from questionnaire responses to questions related to experiences of ICTs, the Internet and online learning, ability to navigate the e-learning environment, utilization of elements of the learning management system and implementation of course ideas in their respective schools and personal lives. The study also provides an opportunity for the author to reflect on her pioneering experiences with e-learning and how she would approach it differently next time. The main lessons learned were that I) the e-learning environment is not necessarily intuitive and participants need opportunities to digest novel features such as the discussion forum; 2) several of the advantages and disadvantages of elearning that appear in the research literature are identified in this study; and 3) setting up an e-learning course is best achieved incrementally.
\end{abstract}

Keywords: E-learning; teaching and learning; school librarianship; information and communication technology

\section{Introduction}

The information and communication technology (ICT) revolution is beginning to impact on the way education is delivered in higher education in South Africa. E-learning, the new kid on the distance-cum-online learning block is emerging slowly but surely as an innovative mode of learning delivery. However, scepticism about e-learning remains. This scepticism has taken various forms, from issues around time, to ICT skills and pedagogy. Educators lacking in technological skills are reluctant to spend time and effort on setting up e-learning courses if time spent on research is more highly regarded by an institution. Students don't always have the requisite ICT skills, access to stable ICT environments and the discipline to study online. Le Grange (2004) suggests, in one argument, that there is merit in the so-called "embodied presence in learning" or face-to-face learning especially in South Africa where people have been racially and culturally divided in the past. E-learning, in this sense, is seen as thwarting progress in overcoming racial and cultural stereotypes as it emphasizes online interactions instead of "embodied" interactions. This scepticism coupled with a hazy definition of e-learning has been fuel for negativity and resistance from academic colleagues. If there is no commonly-agreed upon conception of elearning, there will be misunderstandings and confusion.

Bearing these misgivings about e-learning in mind, the author (I) proceeded to take the risk of pioneering a course in the Advanced Certificate in Education (ACE) School Librarianship, ICT Applications in School Libraries. The University of the Western Cape (UWC) ACE School Librarianship programme began in 2003 as short course offerings replacing the semester-based Diploma in School Librarianship. Each of the 10 short courses takes place over an intensive 5-day period during school holidays. Short course participants use the school term which follows to produce a portfolio of work to demonstrate application of the course at respective schools. Participants are usually school teachers with a certified teaching certificate. Non-teachers (e.g. school library volunteers) can elect to participate in individual courses of the ACE programme.

\section{ICT applications in school libraries}

This was the first course in the ACE School Librarianship to use e-learning. This was also the first time the course was ever offered in the ACE programme. The course's outcomes were the abilities to:

I. Use email. Effective and efficient communication is a fundamental aspect of the Internet. Email is the link between the Web master and the Web site users.

2. Locate and join an education-specific discussion group. Discussion groups or listservs link like-minded people across the globe. Members of discussion groups can ask niggling questions, harvest the ideas of experts, collaborate with colleagues in another country or even find a job elsewhere just by being part of a listserv.

I. Sandy Zinn is a lecturer in the Department of Library and Information Science, University of the Western Cape. South Africa. 
3. Produce a blog. A Weblog or blog is a Web page written like an online diary documenting the person's thoughts on a subject, perhaps with links to bits of useful information and pictures. Weblogs on a school library Web site are a way to share book reviews, hints \& tips for teachers, or research strategies for learners. For the course, participants used the blog as a journaling device to express their individual responses and experiences of the course.

4. Explore e-books. Different kinds of e-books (novels, reference, etc.) were evaluated. Also considered were how they are formatted, their advantages and disadvantages, and examples of e-books, especially free e-books on the Web.

5. Discuss Internet filtering. The topic introduced participants to a discussion about censorship, the use of Internet filtering devices or firewalls and the ethical dilemma librarian's face.

6. Design and create a Web site. Participants were taken on a Cook's tour of selected Web sites which they had to critique using a Web site evaluation checklist. In creating their own school library Web sites, participants had to decide on the name, purpose, audience, objectives and content of the Web site.

The participants in this course were teachers, professional librarians, and school library volunteers (non-professionals).

\section{Rationale for utilizing e-learning}

The synergy between the course content itself and this innovative route (e-learning) to learning provided a fortuitous reason for choosing this particular course to pioneer e-learning. The participants not only learned about ICT applications in the school library such as email, Weblogs and discussion groups but could also experience the new technologies through the use of a learning management system (LMS) such as the Knowledge Environment for Web-based Learning Next Generation (KNG). KNG is an open sourced e-learning platform developed by the University of the Western Cape. It is a learning management system which offers a comprehensive web-based content management system allowing for the distribution of course work, communication, collaboration, content management and assessment.

Going the e-learning route was a pragmatic choice. Numerous enquiries for online learning opportunities in school librarianship spurred me on to devise the first e-learning course. Generally, the short courses in school librarianship attract interested parties from across the provinces because the ACE School Librarianship is offered at only 2 institutions in South Africa, viz., University of KwaZulu Natal and University of the Western Cape. An increasing number of people have access to computers and the Internet at home and their places of work making online learning more attractive and feasible. One way of widening access and satisfying enquiries for online learning was to go the e-learning route. The widening of access is a strong motivator for e-learning (OECD 2005).

The e-learning system permitted a dynamic means to continuing the face-to-face interaction amongst the participants and between the participants and the course facilitator (me). Participants could view the (continually updated) content at any time of day. They could hyperlink to articles held in the library's databases. They could communicate with the lecturer and fellow participants via email, instant messaging, chats and the discussion forum that the system offered. The idea was to take the course beyond the traditional models of one way transmission education (Serfontein 2004).

Another incentive to choosing e-learning was the ability for me to track how often the participants logged on. The participants could upload their work for marking via the system. All the assessment pieces were submitted in an electronic portfolio. There were no exams. The system acted as an archive for work submitted. It was a good information management tool. E-learning offered the participants an alternative way of learning. Distance learning is generally a lonely, non-interactive, paper-based experience. E-learning, if communication features are understood and used, offers interaction. E-learning offers two additional advantages for fulltime workers: flexibility and opportunities for lifelong learning (Engelbrecht 2003). The flexibility of access meant that participants did not have to travel to a venue and could log on when it was most convenient in terms of their daily routines.

The course was offered either in a blended (hybrid) way or purely online. The blended option consisted of 5 days of face-to-face interaction followed by continued interaction using the e-learning system for 8 weeks. The online only elearning option ran for 8 weeks simultaneously. As an accredited UWC course, it was risky to plunge in not knowing whether it would be a success or failure. In change there is always a risk. Human beings resist change as the body (and mind) prefers a state of rest. Educators are no exception. Poole (I99I) refers to "perception, insecurity, homeostasis, conformity, and commitment as barriers to change". We tend to create superficial changes like course name changes or changes in percentages of continuous assessment versus exam (final) assessment. The final reason for opting for elearning, therefore, was to shake up my own pedagogical views by pursuing a more profound change to teaching and learning.

SA Jnl Libs \& Info Sci 2009, 75(2) 


\section{Literature review}

The literature review highlights four areas: the emergence of e-learning, definitions of e-learning, e-learning technology, and challenges to the myths of e-learning.

\subsection{The emergence of e-learning}

Information and communication technologies have presented possibilities for change in the way education is delivered since the advent of radio. With each new ICT medium - television, audio-visual media, CD-ROMs - there has been enthusiastic claims for its effects on transforming education. Similarly Web-based learning with university courses available on Web sites was viewed as progressive. Are these transformative claims warranted? Often the newness of the technological innovation clouds the educational judgment (SAIDE 2000). The focus tends to be on the speed of the rollout of the new technology with minimum thought given to educational principles.

When e-learning emerged about ten years ago, it was a radical concept steeped in hype. The exaggerated promises were:

- A pedagogical revolution: the combination of new ICTs and learner-centred approaches would significantly marginalize the university lecture and create a student who learned independently (Zemsky \& Massy 2004);

- Flexible access to learning: just-in-time learning, flexibility in the tempo of study, more learner accountability for own career growth (Friedland 200I);

- Cost reductions:' - of traditional classroom alternatives' (Engelbrecht 2003). Course material would now be electronically distributed and updated regularly, saving students the purchase of textbooks and course packs (Zemsky \& Massy 2004). Lower travel and accommodation costs would all make e-learning less costly (OECD 2005); and

- Speed: lecturers would be available 24/7 and response times almost instantaneous (McLester 200I).

These inflated promises were quickly quelled by reality as checks pointed to the difficulties people had, for example, in independent learning. Learning new concepts strictly online (McLester 200I) or not interacting with others in a physical place such as a classroom was identified as a drawback. I elaborate further on the myths of e-learning later on.

Today, e-learning is regarded as commonplace in higher education settings, increasingly discussed as inevitable in the school environment (Sadeck 2009) and quite visible in the business sector (South African Breweries; Banks such as ABSA and Nedbank; Telkom). Most universities in South Africa have some form of e-learning component, but the face-to-face classroom remains the dominant form of education delivery. Universities such as Stellenbosch and Pretoria have seen an unprecedented growth in e-learning as their traditional course delivery has mutated into blended learning (Ravjee 2007). Cross-border e-learning initiatives have arisen as can be seen in the African Virtual Open Initiative which enables more than 25 African universities to use the Knowledge Environment for Web-based Learning (KEWL) e-learning platform (Keats 2006) and the international eDegree offerings which work in conjunction with South African universities such as Stellenbosch, UNISA and the University of the Free State (Ravjee 2007). The Western Cape Education Department's elearning directorate has made a strong case for using Moodle, the open source learning management system, in Western Cape schools in the near future (Sadeck 2009).

\subsection{Defining e-learning}

As information and communication technology has evolved, so has the concept of e-learning. At one stage in its evolution, e-learning was considered synonymous with Web-based learning. Web-based learning is largely electronically distributed learning on the Web, for the most part a one way process (the so-called Web 1.0, the first generation of the Web). Others equate e-learning with distance learning. In the latter misconception, it is assumed that educational technology is not used in face-to-face teaching. Traditional lectures regularly do use technology such as email, data projectors and whiteboards (SAIDE 2000). Rosenberg's (200I \& 2006) definition puts e-learning in a nutshell:

The use of Internet technologies to create and deliver a rich learning environment that includes a broad array of instruction and information resources and solutions, the goal of which is to enhance knowledge and performance.

Encapsulated in Rosenberg's definition is the fact that e-learning is about adding value to or augmenting learning by providing access to ICTs and connectivity.

A widely held view posits e-learning as part of the blended learning repertoire in which learning delivery takes a variety of forms (Herselman \& Hay 2005). Some courses are rooted in traditional teaching with Web-augmented lecture notes, email and hyperlinks to online resources. In a different form, Web dependence increases to include online discussion forums, online group work, and online assessment with no real decrease in class teaching. In mixed mode or blended form of delivery, there is more of an emphasis on online collaboration, communication, and assessment and faceto-face teaching is reduced. All of these forms of delivery require a greater or lesser degree of class attendance. The purely online e-learning course accounts for less than $5 \%$ of the total university enrolments (OECD 2005).

SA Jnl Libs \& Info Sci 2009, 75(2) 


\subsection{E-learning technology}

In higher education the academic course is the basic unit for e-learning. Most universities have a networked infrastructure and Internet connectivity for the storage, retrieval, distribution and delivery of information. The technology central to most university e-learning courses is learning management system (LMS) software. Examples of popular commercial LMS software are BlackBoard and WebCT (recently merged with BlackBoard) while Moodle and Drupal are open source products. The features of LMS software are quite similar. They all have:

- Communication features: such as email, chat rooms, instant messaging, discussion forums;

- Course documents: such as reading lists, copyright complied articles and exemplars;

- Course content: a course outline, course outcomes, course sessions and course notes;

- Announcements: important messages posted;

- Assessment: various forms of assessment such as essays, multiple choice questions, tests and worksheets;

- Student personal space: homepage, calendar, bookmarks, own documents, photos;

- Help features: how-to manuals; and

- Course members: participants in the course.

\subsection{Challenging the e-learning myths}

The question arises: if so many universities have a LMS, why do academics have reservations about utilizing them? Some detractors of e-learning contend that ICT is shaping the instructional strategy (Greenagel 2002). In some academic institutions where traditional style lecturing methods prevail, the perception is that the technological aspect of e-learning (the Web) is driving the change. At institutions where the learning strategy is in place, e-learning forms a natural part of that strategy and misperceptions are reduced.

Another argument states that lecturers, used to the traditional knowledge transmission approach, simply do not use the e-learning system to its fullest extent instead limiting usage to electronic "chalkboards". Course notes are uploaded to the Internet without concern for design (they are simply electronic pages) and the predominant one-way transmission of education continues from lecturer to student even with email communication thrown in.

The hype associated with e-learning's emergence has proven detrimental to its real possibilities. Rosenberg (2006), a prominent leader in the field of e-learning, reminds us of the myths of e-learning that possibly fed the negative hype. For example: the myth that "e-learning will eliminate the classroom". Despite the newest learning realm of Second Life, faceto-face classes continue to be the most popular delivery of training. Another untested or exaggerated promise related to cost savings on training delivery. While students may save on travel costs and enjoy flexibility of access times, the asynchronous nature of much of e-learning implies that lecturers need to be more available to respond to student communications.

Allen and Seaman's (2006) research claims that one of the barriers to adopting online learning is academic resistance, as academics need more time and effort to teach online. In academia research is rewarded more highly than innovative teaching (Van der Merwe \& Mouton 2005). This imbalance needs to be corrected in order for e-learning to grow. Universities need to support lecturers' attempts at pioneering novel ways of teaching especially since they shoulder substantial risks (Zemsky \& Massy 2004). Perhaps the time is ripe to change the reward system as it is no longer a matter of if but how (Rosenberg 200I) and how soon we accept e-learning in education.

Academics allude to the need for greater student discipline when learning online as adding to their scepticism of the success of online learning. Yick, Patrick and Costin (2005) in their research on academic experiences of online distance education express academics' reluctance for online education. Online education is perceived as "second best" and time consuming - an add-on to the existing face-to-face courses they teach. It seems that the more e-learning becomes part and parcel of the higher education institution's culture and integrated in the delivery structure, the barriers begin to fall away.

Herselman \& Hay (2005) mention that, in South Africa, the ICT infrastructure may not be in place. The so-called digital divide plays a large part in e-learning course success especially for part-time students whose access to computers and connectivity may be restricted off campus. Apart from computer access issues, Internet access costs, although decreasing year on year, are still quite expensive. Universities may have reasonable bandwidth access, but with only $5 \%$ of South Africans having Internet access in 2006 (Goldstuck) and then mostly from their work places/ institutions, the viability of e-learning is questionable. The My Broadband Web site reported on I March 2006 that most South African users still connect to the Internet using dial-up connections (MyADSL 2006). Interestingly, despite an increase in ADSL connections there has been no noticeable increase in general Internet access. Goldstuck (2006) puts this down to existing Internet users migrating from dial-up to ADSL. 


\section{Research questions}

As this was the first librarianship course in the UWC Department of Library and Information Science to be trialed using the e-learning system and the first time that I had initiated and developed an e-learning based course, it was important to evaluate the course both from the participants' as well as the facilitator's (my) perspective. The study sought to answer two research questions:

- How did the course participants experience e-learning? To what extent were they receptive to e-learning?; and

- Given the prevailing scepticism about e-learning, how did I rise to the challenge of adopting the new mode of course delivery? To what extent was I myself ready to pioneer e-learning?

\section{Data gathering method}

There were 18 participants in the course all working fulltime in an educational institution like a school or college. The schools varied from primary to high schools, public to independent schools, and poor to well-off schools. All the participants were either teachers or librarians/library volunteers. Ten (10) participated in the blended learning environment, 7 as online only participants and I just in the face-to-face sessions. The 10 participants in the blended learning sessions had 5 days of face-to-face interaction followed by 8 weeks of online learning. The 7 online only participants had just the 8 weeks of online interaction. The blended learning participants had a distinct advantage over the online only learners because the blended learning included face-to-face as well as online learning. During the 5-day interaction participants were introduced to the KNG learning environment, presented with lecture-style sessions on the various areas covered such as e-mail, Weblogs, discussion groups, e-books, Internet filtering and Web site design and creation. They also participated in hands-on assessment activities which served towards their final assessment portfolios. One participant attended only the 5-day interaction not wanting to be formally assessed.

As course participants were scattered across South Africa and the United Arab Emirates (one participant), the email questionnaire was the best method for gathering data. To improve the response rate, questionnaires were distributed to all participants both by email and by post. The reason for sending both electronic and printed questionnaires was to exclude problems such as email downtime or lack of printing facilities or paper (many people prefer to work with a paper copy of a survey) as the failure to complete the questionnaire. Anecdotal evidence had alerted me to such possible problems. Participants were sent one reminder in the hope of a better return rate.

The self-administered questionnaire contained a combination of closed and open-ended questions. Using open-ended questions enabled participants to express themselves freely, ensuring a wider array of responses. The closed questions offered suitable categories of solutions from which respondents could chose, assisting me in obtaining accurate information. Questions posed to participants related to:

- Previous experience of ICTs, the Internet and online learning;

- Ability to navigate the e-learning environment;

- Utilization of elements of KNG; and

- Implementation of course ideas in the curriculum.

The open-ended questions were content analyzed while the closed-ended questions were coded, counted and the results entered on to a spreadsheet. Of the 18 participants, 17 were female and I male. None were of Generation $Y$ also called the Millennials i.e. those born between 1980 and 2000 who experience ICTs as ubiquitous. Most were either of Generation X or Baby Boomers. The responses would reveal to what extent participants in the course were receptive to e-learning, whether or not their perceived ICT skills were adequate, and if the course contributed to "real learning"- i.e. putting ideas into practice. The second aspect of the study is based on a reflection on my own practices, involved contributions from course participants and an examination of the research literature on e-learning.

\section{Findings}

Ten (10) of the 18 course participants responded to the survey. Respondents fell into 3 categories: those who participated in the face-to-face training only ( $\mathrm{I}$ person); those who participated in the blended learning (6, the majority); and those who participated online only (3). The findings will be presented under the following headings:

- ICT experience and access

- The ability to navigate the e-learning environment

- Neglect of the discussion forum feature of KNG

- Motivations for participating in the e-learning course

- Deterrents from full participation in the e-learning course

- Implementation of course ideas

A discussion of the findings will be dealt with under a separate heading.

SA Jnl Libs \& Info Sci 2009, 75(2) 


\subsection{ICT experience and access}

Requirements for enrolment in the course were adequate ICT skills such as regular use of search engines for finding information on the Internet, the ability to use the Windows operating system (work with a mouse - left and right click; maximize and minimize the screen; copy/cut and paste; manage files - open, name, save, store, retrieve files), use a word processing package like MS Word 2000/2003 to create, format and edit documents; and the ability to work with images/ graphics. Course participants were sent an ICT skills checklist with the course registration form. The ICT skills checklist was a self-administered form for prospective participants to self-evaluate their skills. They were admitted on the basis of accepting they had these skills.

It became clear during the course that not everyone's ICT skills were at the same level. In the questionnaire, asked whether they thought they had sufficient ICT skills to start the course, most thought they had but a few felt in hindsight that their skills were inadequate. Some participants had problems remembering their user names and passwords for the different applications. The biggest challenge, however, was Web site creation. There was a high correlation between those who found the Web site creation difficult and those who did not use the Internet every day. Perhaps in a future requirement, the stipulation of "daily" usage of the Internet may prove a better term than "regular" usage, the latter being open to interpretation and could mean once per week only.

The research on ICTs in schools (Wilson-Strydom, Thomson \& Hodgkinson-Williams 2005; Howie, Muller \& Patterson 2005; Cohen 2003) continually refers to the lack of access to computers, problems with Internet connectivity and timeconstraints. Bearing this in mind, the participants, who work either in the school or college environment as teachers or librarians, were asked about access to computers and the Internet. The majority could gain access to a computer but Internet access was a problem for two respondents: one whose school's ADSL line was temporarily (six weeks) not working and another whose principal restricted access to the only computer with connectivity in the school. Most of the Internet access was from school via ADSL lines. In Cohen's 2003 report two thirds of the participants interviewed had access only to computers provided by the school. Sebopelo's (2008) Botswanan study produced a similar result.

Technology problems presented themselves in terms of using the Web editor Microsoft (MS) Front Page. Half responded that they sometimes had a problem either with access to or familiarization with the software, especially different versions of Front Page. MS Front Page is not part of the standard MS software bundle and has to be added on.

7.2 The ability to navigate the e-learning environment

Lack of familiarity with an e-learning environment cannot be underestimated. For this reason participants were asked to identify on a Likert scale for five categories their abilities to negotiate the KNG e-learning environment. Figure I summarizes the responses.

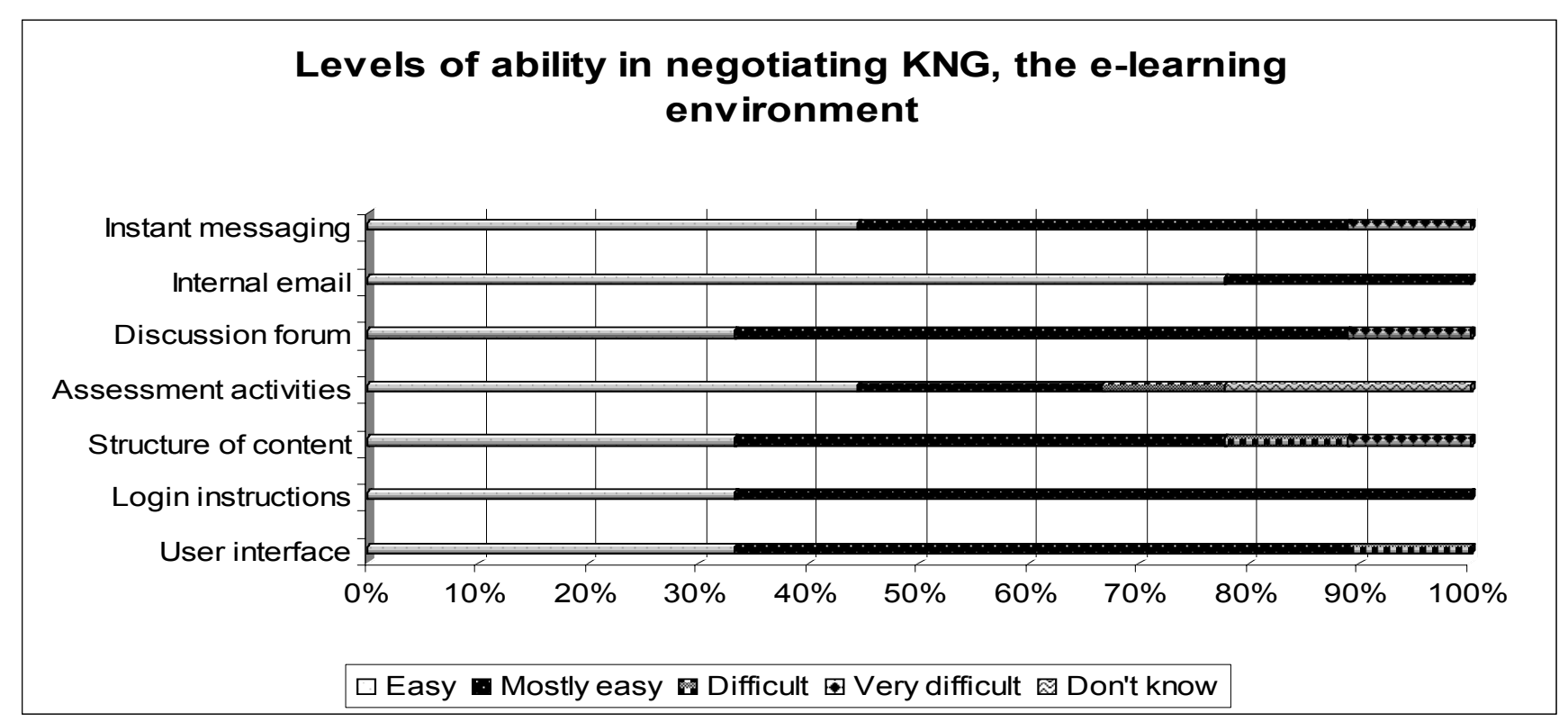

Figure 1 Levels of ability in negotiating KNG, the e-learning environment 
Most participants found the user interface of KNG relatively easy and everybody could follow the login instructions and use the internal email to the system. For one or two, the structure of the content was difficult to follow and navigating the assessment activities was a challenge. These difficulties were cited by the online only participants. When it became evident during the course that participants were having problems with the course structure, I promptly designed two paths: a site map in the form of a course index and a learning pathway for those participants who prefer to learn step by step. Perhaps this was a little too late as some participants dropped out of the course. One participant in particular had serious difficulty with the discussion forum and instant messaging. Although there is a help menu for all these features, the participant refrained from using it.

7.3 Neglect of the discussion forum feature of KNG

Although I promoted the discussion forum, at the time I did not realize the unfamiliarity of the feature amongst participants. This prompted me to include a separate question about the underutilization of the discussion forum. Responses varied but most underlined the fact that the participants thought the discussion forum feature either alien or intimidating.

Those who found it intimidating gave the following reasons for neglecting it:

- Lack of confidence in expressing oneself in English as English is not the home language; and

- Lack of confidence in sharing thoughts.

- Those who found it alien said that they had not used the forum because:

- They had never encountered one before;

- They did not see the point of sharing thoughts and ideas with others;

- I, as course facilitator, had not explained the importance of the discussion forum as a communication and collaboration tool; and

- It took a while to understand how to use it.

There were a few other reasons for not using the forum such as not accessing the Internet frequently enough and being disheartened by the few replies on the forum.

Serfontein (2004) in his study of economics students at UNISA comments on the underutilization of the discussion forum. He too signals that it should be part of the assessment as one student suggested in the present study. Students need time to practise and become familiar with unknown tools.

\subsection{Motivations for participating in the e-learning course}

I wanted to gauge what spurred on the participants to join the course. All respondents wanted to learn to use the new technologies associated with blogging and Web site creation. Half the respondents also liked the flexible learning approach. For example, learning when the time suited them; at their own pace; not traveling to a venue; etc. The research literature supports this positive remark about e-learning's advantages (Friedland 200I). A few opted for the course because it was inexpensive while others needed the course for completion of the ACE School Librarianship programme. Learning new technologies and flexible learning attracted all of the online only participants.

E-learning offers part-timers flexibility in learning. Most respondents preferred to go online early morning, some before school and some at school but before 10:00. Reasons given ranged from feeling fresh and wide awake at 5:00 a.m. to claims that the Internet was faster before 10:00. A few respondents opted for evenings as their best times. The main reason provided was "quiet time" or fewer interruptions. Another view for choosing evenings was the cheaper rate after 7 p.m. for dial-up connections and faster Internet service.

\subsection{Deterrents from full participation in the e-learning course}

The appeal of the course and flexible delivery mode did not translate into full participation by all. I was therefore eager to find out what had deterred participants from participating fully. Participants could choose from amongst 5 statements supplied or they could specify their own reason (See figure 2). As full-time teachers or librarians/library volunteers, most participants described their biggest obstacle to participating as setting aside enough time. Many also maintained that they had underestimated the required time to participate fully. Several studies on the obstacles to the success of e-learning cite the lack of discipline amongst students (Allan \& Seaman 2006; Friedland 200 I; Yick, Patrick \& Costin 2005). A few of the participants felt that the order of learning or how to proceed was a stumbling block. Similarly, a few found the KNG navigation a major drawback. These last two comments are particularly relevant for online learning and reflect the poor design of the Web site which was later improved upon by incorporating an index and a learning pathway.

A couple of participants described their feelings as being overwhelmed generally and by technology specifically. This response harks back to the initial ICT skills required of participants for the course but which had been found wanting.

SA JnI Libs \& Info Sci 2009, 75(2) 


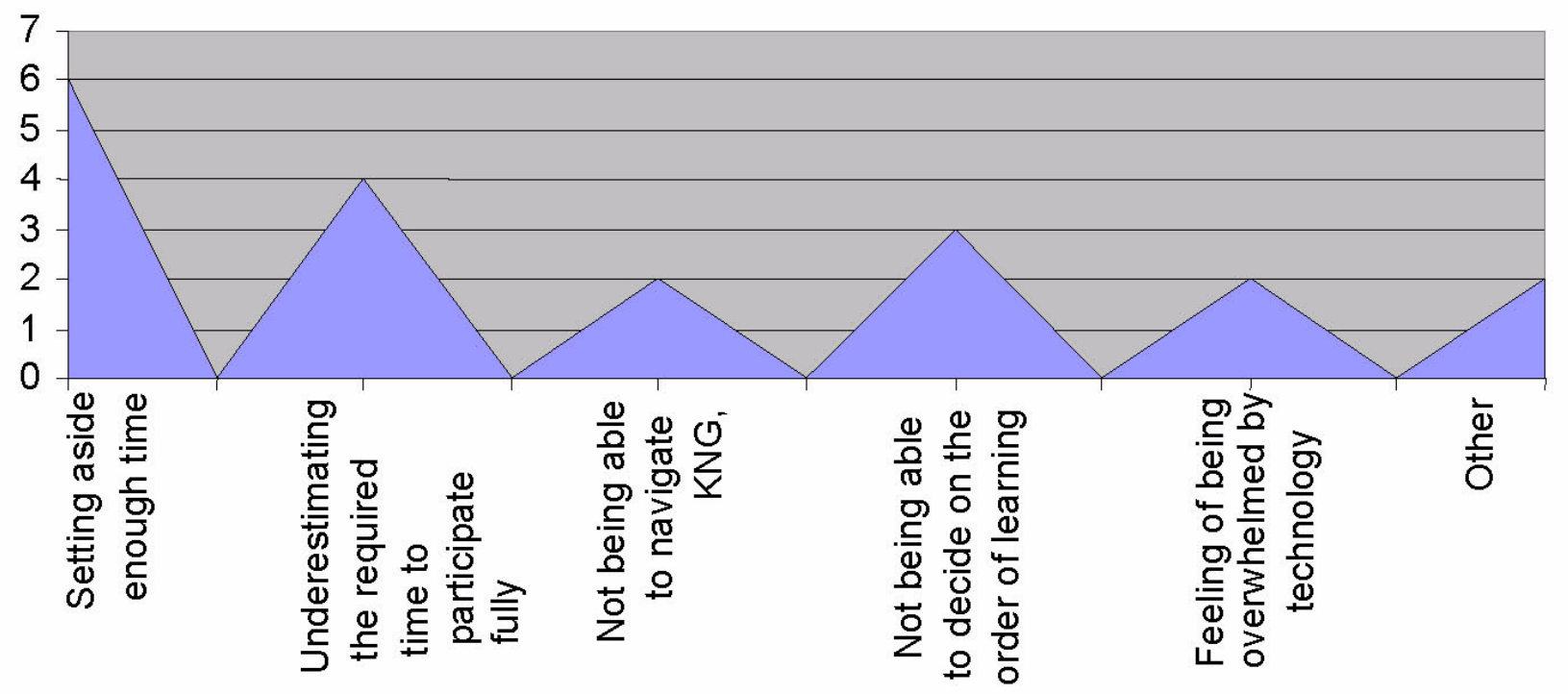

Figure 2 Deterrents to course participation

\subsection{Implementation of course ideas}

The success of the course rested on whether or not participants had applied their learning in their educational or personal environments. Participants were asked if they had implemented any ideas from the course. Most popular applications were email, discussion groups and Web sites. The feedback was heartening and is summarized as follows:

- Respondents who had never used email before were now confidently teaching email usage to learners.

- Some still subscribe to discussion groups or have joined new discussion groups.

- A few are promoting discussion groups with learners.

- Respondents have created new blogs.

- Some have taught Web site creation to learners.

- A few have assisted colleagues with Web sites.

- Participants are helping the Information Technology (IT) teacher with the school's Web site.

- One respondent has taken over updating the school's Web site, a task usually delegated to the IT person! Internet filtering was a topic which participants had to research and write a report on. The topic introduced them to a discussion about censorship, the use of Internet filtering devices or firewalls and the ethical dilemma librarians' face. A few respondents found the topic interesting enough to either discuss with colleagues or with the IT teacher who is usually tasked with such issues as firewalls and Internet security.

All in all, the experience for the majority of respondents was positive. When asked whether they found using the elearning mode tiresome or novel, the majority found it fresh and innovative.

\section{Discussion of major findings from the questionnaire}

The major questionnaire findings are:

I. Individuals' progress in new ICT acquisition varies depending on their starting point.

2. The e-learning environment is not necessarily intuitive. Participants need time to familiarize themselves with each aspect thoroughly. Course goals and objectives need to be well understood and novel e-learning elements such as the "discussion forum" should be integrated into the assessment activities.

3. The advantages of e-learning as discussed in the literature such as the flexibility of time and place to learn, etc. are confirmed in this study.

4. The downside of e-learning is the lack of time management and, in this study, the lack of Web site navigational cues. 
5. The participants are nearest the UNESCO ICT integration level of 3 in the UNESCO four-stage continuum model for ICT integration and teacher development. They are not using ICTs merely for administrative and management tasks but for curriculum integration.

It became apparent during the course, the ICT applications in school libraries, that some participants' ICT abilities were inadequate not because they lacked the skills but because they had had insufficient practice. This resulted in a slower uptake of newer ICT skills such as required in Web site creation.

Most respondents (9) had never before participated in either blended or online learning. The latter is in line with other studies emerging from Africa (Sebopelo 2008). The lack of familiarity with an e-learning environment cannot be underestimated. The online only respondents had great difficulty with navigating the structure of the content and the assessment. The navigational structure had seemed intuitive during the face-to-face sessions probably because participants had been guided. By the time a site map and learning pathway had been added, several online participants had dropped out.

The "discussion forum" was a totally novel idea to all participants. What I as course facilitator naively expected from participants was an instinctive adoption of the forum for sharing ideas, asking questions, and bolstering each other. For the successful uptake of the discussion forum, thorough planning and analysis are required (Giannini \& Seleka 2005). The course facilitator needs to answer the following questions: Does the e-learning community have sufficient ICT skills for using the discussion forum? Have activities been built into the course to make participants feel comfortable in the discussion forum? Do participants understand the important role the forum plays in achieving some of the course objectives? In hindsight I realize that not enough planning and thought went into the utilization of the discussion forum. As Serfontein (2004) suggests, next time it should be promoted, practised and included in the assessment.

McLester (200I), Eastmond et al., (2000), Friedland (200I) and Sebopelo (2008) convey strong arguments for the opportunities that e-learning have to offer such as:

- The convenience of accessing a course from any geographical location.

- Offering a sense of anonymity to participants who may be shy to speak in traditional classes, lag behind because they require more time to respond, or those with other disabilities.

- Enabling participants to upgrade their knowledge and skills whilst remaining in the workplace.

- The flexibility of time and pace of learning.

The respondents in my study confirmed three of the above-mentioned advantages but nobody commented on the benefits that anonymity may bring. This may be because anonymity was not explicitly mentioned.

The major stumbling blocks in the way of full course participation were time demands, e-learning navigation, and technology "fatigue". In terms of the UNESCO four-stage continuum of ICT integration as a measure of ICT curriculum and teacher development (Wilson-Strydom, Thomson, \& Hodgkinson-Williams 2005), the respondents are clearly nearest stage three, the 'infusing' stage, where ICT begins to be integrated across the curriculum. The course was intended to be largely practical with participants producing an electronic portfolio of work providing evidence that they had produced a Weblog, joined a school library discussion forum, produced a school library Web site, and so on. Participants in fact demonstrated that they had successfully transferred their learning in the course and applied it in their respective educational and personal environments.

\section{Reflections on my e-learning practices}

One of the objectives of this study was to reflect on my own practices by examining how prepared I was as course facilitator to use e-learning, a new mode of course delivery, given the prevailing scepticism.

The literature categorizes people's adoption of technological innovations according to the following patterns (Zemsky \& Massy 2004; Engelbrecht 2003):

- Innovators ( $\pm 3-4 \%$ ): these are the audacious few who take risks trialling new ideas driven by a fundamental belief in the potential of their new innovation.

- Early adopters ( $\pm 15 \%)$ : adopters of new ideas, opinion leaders, risk takers in their realization of the new innovation.

- Early majority ( $\pm \%)$ : more followers than leaders but ready to adopt new ideas before the other half of the population. Considered 'change agents' by their peers.

- Late majority ( $\pm \%)$ : definitely followers, cautious and sceptical, adopt under duress.

- Intransigents (( $\pm 15 \%)$ : the 'die-hards' or resisters avoid the innovation despite the clear benefits.

Using these categories as my guide, I fall into the "early majority" group of adopters of e-learning - a change agent. As one of the first lecturers on the UWC campus to pilot a course on the e-learning KNG LMS, I consider my actions to be pioneering. Accompanying any trailblazing project is risk of some kind.

SA Jnl Libs \& Info Sci 2009, 75(2) 
Developing a new course using new technology was a challenge. Many studies (for example, Van der Merwe \& Mouton 2005; Engelbrecht 2003; Le Grange 2004; Yick, Patrick \& Costin 2005) assert that lecturers refrain from using elearning for numerous reasons amongst which are

- a lack of ICT skills;

- the time needed to invest in learning;

- a lack of know-how to integrate ICTs into courses;

- time consumed in interaction with students online; and

- an academic reward system that either overlooks teaching and learning innovation or relegates it to the bottom echelon of the system.

My ICT skills were reasonably good but, although I had been exposed to online course design before, I had never created an e-learning course from scratch. This weakness was soon exposed by the online only participants who had difficulty with the course navigation and rectified by the creation of a course index and learning pathway respectively.

I was aware of some pitfalls such as lapsing into delivery or transfer of content and managing performance rather than managing learning. Technology provides the landscape or environment for teaching and learning to take place (Keats 2006; Rosenberg 2001 \& 2006). Whether or not that enabling environment enhances knowledge construction or solution finding, depends on the pedagogical paradigm or framework within which one is operating. For example, traditional transmission-styled education, of which Greenagel (2002) is critical, can coexist within new technologies. At the same time I was cognizant of my participants who were schooled in the chalk-and-talk approach and who did not always embrace the collaborative learning model of the e-learning LMS. A case in point is the participant, reported on earlier, who did not understand how contributing to the discussion forum could help her learn.

\section{Conclusion and recommendations}

The main purpose of this study was, firstly, to find out how participants in an ACE school librarianship course experienced e-learning for the first time, and secondly, how I as course facilitator and "newbie" to e-learning myself, measured up to e-learning's demands.

In terms of the first objective of the study, the majority of respondents demonstrated that they were keen and willing to embrace e-learning, despite a few challenges such as lack of requisite ICT skills and time. The course provided a way for participants to upgrade their ICT knowledge and skills. It has not gone unnoticed that most participants were Generation X-ers or Baby Boomers eager to learn the new technologies. As part-timers juggling work, family and study, time management emerged as an issue. Ideally, participants needed Internet access at home and school but most could only access the Internet at school. The Draft White Paper on e-Education (South Africa 2003) supports the idea of subsidies and loans for teachers to purchase home computers.

In terms of the second objective, in order to become a more effective librarian educator one's teaching practice requires regular scrutiny. This reflection has generated a deeper understanding of my own teaching style. Moreover, by challenging traditional teaching styles in this study, reflection has helped me to validate my beliefs about what constitutes good teaching and helped me to grow professionally (Ferraro 2000). Being a "change agent" and risk taker has propelled me into a pioneering role in e-learning in librarianship. There were challenges which may relate to having adopted two forms of e-learning in my first e-learning attempt viz. a blended and an online only approach to e-learning.

To improve my practice, I asked participants for suggested changes to the e-learning mode of delivery. They provided me with invaluable insights which I table below as part of the recommendations. Recommendations for future e-learning courses:

I. Learning online requires regular engagement with participants (mentoring) otherwise they tend to drop out;

2. Allow ample opportunities for participants to familiarize themselves with all the e-learning features;

3. Ensure that communication and collaboration tools such as discussion forums or any other novel e-learning application is well explained and clearly designated as part of the assessment;

4. Introduce e-learning incrementally if it is your first attempt. Avoid using all the different forms of e-learning at once;

5. Prepare for as many eventualities by offering a variety of access routes to the course content and structure e.g. site index, learning pathway, frequently asked questions (FAQs) incorporating text and visual learning styles such as videocasts and slide shows; and

6. Become part of the lobby group that puts pressure on the university management to reward teaching and learning innovation equitably.

This study has illustrated that e-learning, despite various challenges, is a viable route to learning.

SA Jnl Libs \& Info Sci 2009, 75(2) 


\section{References}

Allen, I.E. \& Seaman, J. 2006. Making the grade: online education in the United States. Needham, MA: Sloan-Consortium. [Online]. http://www.sloan-c.org. Accessed I 8 November 2006.

Cohen, S. 2003. Report on the use of ICTs in schools research Project. Johannesburg: South African Institute for Distance Education (SAIDE).

Eastmond, J.N., Nickel, T., du Plessis, J. \& Smith, L.D. 2000. An incremental approach to implementing a Web course. TechTrends, 44 (3):40-45.

Engelbrecht, E. 2003. E-learning - from hype to reality. Progressio 25(I):20-3I.

Ferraro, J.M. 2000. Reflective practice and professional development. [Online]. http://www.ericdigests.org/200I-3/reflective.htm. Accessed 30 April 2009.

Friedland, C. 200I. The application of information and communication technologies in learning and training in developing countries. Karlsruhe: Karlsruhe University of Applied Sciences. (Master of Computer Science thesis).

Giannini, D. \& Seleka, G.G. 2005. Experiences with online discussion forums in developing countries: comparison of 'DAE 642 Adult Education and Development' and 'BIS 204 Data Organization Methods' at the University of Botswana. [Online] http:// emerge2004.net/connect/site/UploadWSC/emerge2004/file23/2004\%2006\%201 7\%20Giannini\%20Seleka\%20Paper.pdf. Accessed 30 September 2005.

Goldstuck, A. 2006. The Goldstuck Report: Internet Access in South Africa 2005. [Online]. http://www.worldwideworx.com/ archives/39. Accessed 6 August 2007.

Greenagel, F.L. 2002. The illusion of e-learning: why we are missing out on the promise of technology. Phoenix: League for innovation in the community college, White papers. [Online]. http://www.league.org/publication/whitepapers/0802.html Accessed I 5 November 2006.

Herselman, M.E. \& Hay, H.R. 2005. An investigation into e-learning practices: implications for providers of education and training. South African Journal of Higher Education, 19(2):393-4I0.

Howie, S.J., Muller, A. \& Paterson, A. 2005. Information and communication technologies in South African secondary schools. Cape Town: HSRC Press. [Online]. http://www.hsrcpress.ac.za. Accessed 22 February, 2006.

Keats, D.W. 2006. The genesis and emergence of education 3.0 in higher education: the potential for Africa. Keynote paper presented at the Global Learn Day X, Africa Program, October 8, 2006. [Online]. http://ben300.com/GLDTEN/?p=40. Accessed October 152006.

Le Grange, L. 2004. E-learning: some critical thoughts. South African Journal of Higher Education, I8(I):87-97.

McLester, S. 200I. Convergent learning: redefining the education experience. Technology \& Learning. [Online] http:// www.techlearning.com. Accessed I February 2002.

MyADSL. 2006. Broadband overtakes dial-up in the UK. [Online]. http://mybroadband.co.za/nephp/?m=show\&id=2076 (I March). Accessed 7 June 2008.

OECD 2005. Policy brief. E-learning in tertiary education. [Online]. http://www.oecd.org/dataoecd/55/25/3596I/32.pdf. Accessed 26 May 2006.

Poole, W. 199I. Resistance to change in education: themes in the literature. [Online]. http://eric.ed.gov/ERICDocs/data/ericdocs2sql/ content_storage_0l/00000/9b/80/22/d9/cf.pdf. Accessed 19 May 2002.

Ravjee, N. 2007. The politics of e-learning in South African higher education. International Journal of Education and Development using Information and Communication Technology (IJEDICT), (3) 4:27-4I .

Rosenberg, M.J. 2006. Beyond e-learning: approach and technologies to enhance organizational knowledge, learning and performance. Oxford: John Wiley \& Sons, Inc.

Rosenberg, M.J. 200I. E-learning: strategies for delivering knowledge in the digital age. New York: McGraw-Hill.

Sadeck, O. 2009. Learning management systems: an e-learning platform for WCEDschools and FET colleges. Cape Town: WCED. [Online] http://curriculum.pgwc.gov.za/resource_files/I56102753_Ims_elearn_wced_report.pdf. Accessed I4 April 2009.

SAIDE 2000. Lessons in the application of educational technologies in South Africa. [Önline]. http://www.saide.org.za. Accessed I5 March 2007.

Sebopelo, P. 2008. Exploring the introduction of e-learning as an open and distance learning delivery mode in Botswana. Paper presented at the Commonwealth of Learning's fifth Pan-Commonwealth forum on open learning, University of London, 13 17 July 2008. [Online]. http://www.wikiteacher.org/4/48/PID_7I.pdf. Accessed I November 2008.

Serfontein, F.H.B. 2004. A workable e-learning strategy for distance education in South Africa. Proceedings IEEE International Conference on Advanced Learning Technologies, 30 Aug.-I Sept. 2004.

South Africa. Department of Education. 2003. Draft White paper on e-education: transforming learning and teaching through information and communication technologies. Pretoria: The Department.

Van der Merwe, A \& Mouton, J. 2005. Integrating ICTs into the teaching and learning environment: an investigation of lecturer perceptions of possible barriers and incentives. Perspectives in Education, 23(4): 19-37.

Wilson-Strydom, M., Thomson, J. \& Hodgkinson-Williams, C. (2005). Understanding ICT integration in South African classrooms. Perspectives in Education, 23(4):7I-85.

Yick, A.G., Patrick, P. \& Costin, A. 2005. Navigating distance and traditional higher education: online faculty experiences. International Review of Research in Open and Distance Learning 6(2). [Online]. http://www.irrodl.org/index.php/irrodl/article/ viewArticle/235/320. Accessed 30 November 2006.

Zemsky, R. \& Massy, W.F. 2004. Thwarted innovation: what happened to e-learning and why. [Online]. http:// www.irhe.upenn.edu/WeatherStation.html Accessed 14 June 2006.

SA JnI Libs \& Info Sci 2009, 75(2) 